\title{
A Way Head to Nation Fragmentation: Challenges of Politicized Statehood Narratives and Identity Politics in Ethiopia
}

\author{
Esubalew Aman Mezmir \\ Lecturer at Wolkite University, Department of Sociology
}

\begin{abstract}
This paper set out to confer an argumentative essay on the contemporary challenges of politicized statehood narratives and identity politics in Ethiopia. In doing this my argument is mainly supplemented with secondary source of data. Accordingly, books, articles, and different published materials were critically reviewed. Based on a critical review of the existing literatures I argued that with the coming of ethnic identity as the mainstay of Ethiopian politics,displacements of civilians, ethno-centric-prejudice, inter-ethnic mistrust, and a sense of insecurity especially by non-ethnic residents of given places has been increased.Along with this, ethno-centric fundamentalist elites disseminates politicized statehood narratives that intends to depict 'past historical injustice' as being committed by the 'Amhara ruling-class' against all other ethnic group of the nation. Therefore, in my point of view the increasing number in the displacements of civilians, ethno-centric-prejudice, inter-ethnic mistrust, and a sense of insecurity especially by non-ethnic residents of given places in Ethiopia are looked to be directly or indirectly rooted from elites fabricated and politicized statehood narratives and identity politics. Hence, this condition is not alleviated soon it may lead the nation to path of fragmentation.To this end, in this paper I suggest that before going to take any measures to control and manage the country from being fragmented, we should first create national consensus based at forgiveness regarding what was happened in the past. Then we should clearly know the deep rooted nature and challenges of applying identity politics in the federal state of Ethiopia and must come up with sound systems that can promote sense of Nationalism in the first place.
\end{abstract}

Keywords: Identity Politics, Politicized Statehood Narratives, Ethno-centrism, Nationalism, and Nation Fragmentation.

DOI: $10.7176 / \mathrm{IAGS} / 87-01$

Publication date:October $31^{\text {st }} 2020$

\section{Introduction}

Since the Ethiopian People's Revolutionary Democratic Front's (EPRDF) came to power in 1991, it came with a political ideology to make ethnic identity the mainstay of Ethiopian politics and ethnic identity has been used as a showcase through which different interest groups define and present their respective abstract concern. With an emerging competing claim of interest across different ethnic groups, striving to project ethnic interest first, ithasbecame new sources of domestic and international tensions. This could be manifested with a resurgence of ethnic conflict in different parts of the country. Such conflicts seem to be characterized by their protracted nature and a potential for bringing about extreme violence and atrocities against civilians. Moreover, political and intellectual elites attempt to use fabricated (politicized) statehood narratives in order to legitimize particular political programs in the contemporary context.

Hopes that the reform emerging after Prime Minister Dr. Abiye Ahmed has come to power might usher Ethiopia in an era of peacebetweenandwithinthenations. As Messay Kebede (2019) has argued, there is no denying that the coming of Abiye Ahmed as prime minister and his surprising pan-Ethiopian commitment as well as the numerous steps he took both to correct the repressive and grossly abusive nature of the previous government and to widen the political space have altered the political debate in Ethiopia in a positive way. It is equally true that it has raised great expectations that are difficult to satisfy because the people and the various political movements anticipate different, if not opposing outcomes, from the change. With the date of scheduled national elections fast coming, uncertainties and suspicious are growing along with the displacements of civilians, ethno-centricprejudice, inter-ethnic mistrust, a sense of insecurity especially by non-ethnic residents of given places which are essentially triggered by forces attempting to change the direction of the ongoing reforms or fighting to reverse them.

From my point of view, the oftenblamedfortheincreasing number of the displacements of civilians, ethnocentric-prejudice, inter-ethnic mistrust, and a sense of insecurity especially by non-ethnic residents of given places are looked to be directly or indirectly rooted from elites fabricated and politicized statehood narratives and identity politics. The phenomenon was commonly associated with the multifaceted nature of ethnocentrism, a strong sense of ethnic self centeredness, which involves expressions of intra group ethnic preference rather than securing national interest. In line with this, as Taye Nigussie (2018) has mentioned what is least controversial is the fact that by its very nature ethno-centric identity is bound to portray one's world in terms of the polarized social 
domains of "us" and "them". Unfortunately, this alienating and polarizing ideology is crowning in Ethiopia at the time when the world is ever getting closer to form a unified human community owing to the ongoing globalization.

Considering the above facts, I argued that identity politics based at ethnic identity and politicized statehood narratives concerning some ethnic groups has always been the major source of growing political tension in Ethiopia. As a result,it has resulted for massive displacement of civilians, ethno-centric prejudice, inter-ethnic mistrust, and sense of insecurity especially by non-ethnic residents of given places in the nation. These gave identity politics a bad name and also meant that it tended to be linked with the newly emerging quest of different ethnic groups for exercising the right to self-determination up to succession, hence it may lead the nation in a path to be fragmented.

To this end, in this paper I suggest that before going to take any measures to control and manage the country from being fragmented, we should first create national consensus based at forgiveness regarding what was happened in the past. Then we should clearly know the deep rooted nature and challenges of applying identity politics in the federal state of Ethiopia and must come up with sound systems that can promote sense of Nationalism in the first place.

\section{Identity Politics and Historical Statehood Narratives}

General theories of nations and nationalism are unhelpful when it comes to address particular cases, principally because very few cases adhere to the accounts they offer. I do not intend to rehearse these arguments here or to explore the relative merits of different theories with regards to Ethiopia. Instead, I propose different approach for studying contemporary Ethiopian national identity. I argue that national identity is constituted by the interaction of different levels of social abstraction. The first level is an abstract level of 'big stories' which has been done by our ancestors. The second level looks at the political and intellectual elites who attempt to make sense of these 'big stories' in order to legitimize particular political programs in the contemporary context. Thus the narratives of national identity articulated by political and intellectual elites are manifested and constantly reinterpreted in social practice. With the coming of identity politics in Ethiopia competing political parties and intellectuals mobilized and reinterpreted statehood narratives of the nation in order to legitimize their political programs.

With this regard, Taye Nigussie(2018) has noted that Ethiopian People's Revolutionary Democratic Front's (EPDRF) ideological discourse has it that the reason for instituting an ethnic based federal state in Ethiopia was mainly because of the need to reduce 'past historical injustice' committed by the 'Amhara ruling-class' against all other ethnic groups. This is essentially a reductionist ideological construct apparently coined to serve political purposes. Therefore, for Taye truth has to be told in a way that the forms of prejudices and repressions in the course of many centuries' long interactions and contentions among a number of social entities in Ethiopia were of remarkably complex and quite varied in nature.

Moreover, as Messay Kebede (2019) has argued, there is little doubt that identity based politics in Ethiopia, besides being imposed, is deliberately established to encourage ethnicization. Whereas other countries use federalism as a devise to dilute ethnicity so as to safeguard national unity, all the practices and constitutional provisions in Ethiopia tend to strengthen ethnic identity to the detriment of national integration. The explanation is not hard to find: both to mobilize the people so as to overthrow the perceived dominance of the Amhara elite and to establish a federal system that favours it, the TPLF, as a representative of a minority ethnic group, was redefining historicity of the Ethiopian state and Ethiopianness. To this effect, I argue that at the most abstract level national identity in Ethiopia is leashed out by politically induced reconstruction and reinterpretation of nationhood historical narratives.

\section{Identity Politics as a Theoretical Framework}

Identity politics as a political concept refers to the political activity of various ethnic, religious and cultural groupings in demanding greater economic, social and political rights up to self determination. Identity politics claim to represent and seek to advance the interests of particular groups in the society, members are often share and unite around common experiences of actual or perceived social and economic injustice, relative to the wider society of which they form part and exist in. In this way, identity of the oppressed group gives rise to a political basis around which they may unite and begin to claim themselves in society (Zweiri and Zahid, 2007).

In this regard, most of the ethno-centric fundamentalistshave attributed the seemingly legitimate premise of reviving and reincarnating some allegedly endangered or lost identities for their participation. However, this really tells very little about the true essence and ultimate object of many. As Taye Nigussie (2018) has suggested a serious endeavor to get a sense of the true nature of such subtle politics must go much further than the facadeappearance.

A quick review of literature in this regard reveals that the real issue can only be glimpsed in the unwritten and implicit assumption of the fundamentalist ethno-centric ideology which centers on achieving their respective latent personal goals. Along with this, I can argue that Ethiopia asa nation has become deeply divided, fragile, and unstable, because there are fewer points of convergence and consensus among citizens to effectively mitigate that tear the society apart. Moreover, as a result of the pluralistic nature of the society and the very nature of identity politics, Ethiopia has faced a continuing crisis of nationalism, which has often challenged its efforts at national 
cohesion, democratization, stability and economic transformation.

\section{The Nature of Ethnic Based Politics in Ethiopia}

As Roxana (2010) mentioned, Ethnic identity in many African countries influences political and social behavior. Accordingly, Ethnic identity influences that one trusts, does business with, gets married to and whom to vote for. The reasons why ethnic identities play such a strong role in African's lives is still debated. Some argue that ethnicity is hard-wired within the socio-economic system, it is the way people have learned to live and there are no incentives to change. In the case of Ethiopia I argue that ethnic identity has influenced many aspects peoples life. This could be manifested in different forms; mainly itis serving as a potentialsource for displacement of civilian, ethno-centric prejudices, inter-ethnic mistrust, a sense of insecurity especially by non-ethnic residents of given places, and it also determines voting intentions in the political spheres.

For instance, since voting patterns are characterized by ethnicity, access to public services, incidence of poverty and wealth difference amongst ethnic groups, people tend to vote for candidates in line with the politician they have best suits their ethnic interest. To this effect, the rest out of the ruling ethnic groups on the political sphere could feel marginalized and desperately may want another ethnic group at the helm of affairs to ensure the rotation of power amongst the diverse ethnic groups.

According to Nnabuihe et al (2014), ethnic nationalism is a stronger or extreme form of ethnicity. While ethnicity is pursued within the framework of a state, ethnic nationalism seeks for attainment of sovereignty or statehood for an ethnic group. Both terms are applicable to the Ethiopia situation as various ethnic groups has at one time or the other has expressed the desire for independence from the federation which reached its peak with aggravating internal conflicts in the nation. Considering the ample amount of observation in politics of the nation, I can evidently argue that ethnicity determines every aspects of citizen's life. For instance, the electoral choice of Ethiopians is ethnically colored as party formations are ethnically designated and motivated. Hence, most of the political parties in Ethiopia do not have national platform.

\section{Identity Politics as a Condition for Nation Fragmentation in Ethiopia}

The so-called 'EPRDF government' established a federal system focusing on ethnic identity after ratifying the new constitution in 1994. The 'EPRDF's constitution' Article 47 (1) classifies the member states of the 'Federal Democratic Republic of Ethiopia' into nine regional states. As Legesse (2015) has argued, the indivisibility of the Ethiopian nation which has been the result of thousands of years of interaction has been eroded and the stable ethnic composition has been disrupted by the introduction of ethnic federalism, so that Ethiopians are now at odds along ethnic lines. Ethnicity which is driven by the politicization of tribal identity has the tendency to cause problems in the nation.

To quote Bekalu (2017) "since the advent of ethnic federalism that politicized tribal identity, there have been a number of conflicts, cases of ethnic cleansing and unspeakable crimes committed against humanity in the country; and all these have taken place without fair responses from the EPRDF/TPLF government". In this regard, Ethnic based politics generates hostility amongst Ethiopia's different ethnic groups that hinders group interaction and entails ethnic conflicts. Due to the nature of ethnic based politics, mutual suspicion and hostility causing ethnic cleansing and conflict are bound to emerge by default. To this end, the politicization of tribal identity, the design of the federal state, fiscal federalism, and dominant party governance are condition that make identity politics a major source of ethnic conflicts, deriver for ethnic groups quest for self determination, and a way head to nation fragmentation in Ethiopia.

\section{The Politicization of Tribal Identity}

Considering the observed reality of the nation, ethnic conflict in Ethiopia cannot be blamed on the mere existence of many ethnicities, but rather on the politicization of ethnic identity by self-centered politicians and political elites of the nation. In light of this, of all the modalities of federalism (territorial, multi-national, ethnic, quasi-federal), ethnic federalism, with its politicizing of ethnic identity, is obviously the one that can cause inter-ethnic problems. Abbasi (2010) mention that if ethnic differences are high and politicized and if 'federal bargain' type solutions are difficult to achieve, then decentralization may result in greater ethnic mobilization and may lead to secession.

Moreover, due to identity politics, ethnic group members are forced to vote for their ethnic party, which increases ethnic grievance and the probability of eroding feeling of nationalism. As can be seen from previous experience of the nation, there was a number of ethnic conflicts in Ethiopia since the introduction of ethnicity as the backbone of political life. For instance, we can see the case of the two tribes (Guji and Borena Oromo) that have historically managed to peacefully alternate control of their own region, have clashed since the fact that the 'EPRDF government' has supposedly been inciting leaders of the subgroups (Holder et al. 2006). These scholars further state, that the current situation in Ethiopia presents dangers that could affect all ethnic groups in the future. That is, the federal system of government with the politicization of tribal identity could cause deep ethnic division that brings multiple problems such as secessionist movements and a culture of mistrust among different ethnic 
groups of the nation.

As noted in the foregoing paragraph, the 'EPRDF's constitution' Article 47 (1) classifies the member states of the 'Federal Democratic Republic of Ethiopia' as nine regional states and divided Ethiopians along ethnic lines thus institutionalizing their divisions. Furthermore, the constitution itself has the potential to invite conflict as in the case of self-determinism. Article 39 (1) of the Federal Constitution states: 'Every Nation, Nationality and People in Ethiopia has an unconditional right to self-determination, including the right to secession'. Considering article 39 (1), I strongly mention a government that is concerned with the wellbeing of a nation should not constitutionally encourage ethnically grouped people to set apart from the whole nation. Taking this article into account, some groups, such as the Oromo People Liberation Front (OLF) and the Ogaden National Liberation Front (ONLF), have fought against the federal government claiming the right to self-determination up to secession.

Bekalu (2017) has mentioned Article 39 (1) of the Federal Constitution as potential source to create lasting conflict, distrust and hatred among ethnic groups in the nation. Vestal (1999) has suggested that mistrust and hatred among ethnic groups grow out of the EPRDF's theory of governance. In my point of view, it was not only the central policy of ethnic federalism that intensifies tensions and conflicts, but decentralized ethnic-based administrations were also planting seeds of ethnic awareness and antagonism. In other words, ethnic politics is able to divide the society, and ethnic groups are likely to develop mistrust against one another.

Alemante (2003) has proposed prohibiting discrimination on the basis of ethnicity, providing individuals with equal rights regardless of their ethnic identity, and banning ethnic politics or parties, as solutions to get rid of challenges related to ethnicity. For example, the multi-national western federations (such as Switzerland and Canada) do not support ethnicity as the chief instrument of state organization. Even in African countries, such as Uganda and Eritrea, tribal or religious parties are discouraged (Mesfin, 1999). The Ghanaian Constitution, Article 55 (4), prohibits tribal or ethnic-based political parties and it clearly states 'Every political party shall have a national character, and membership shall not be based on ethnic, religious, regional or other sectional divisions'.

Contrarily, the EPRDF Constitution, Article 46 (2), encourages ethnicity and tribal affiliation, and blatantly declares: 'States shall be structured on the basis of settlement patterns, language, identity and consent of the people'. Ethiopia and Ghana are multi-ethnic societies with ethnic inequalities and historical rivalries but in Ethiopia, ethnic politics are the foundation and the lifeline of political elites which requires states to be structured as homogeneous tribal homelands (Alemayehu, 2015). Accordingly, above hundred ethnically organized parties are found in the Ethiopian political landscape.

In view of the above, a non-ethnic, non-tribal multi-party democracy is the only viable option that could guarantee to promote feeling of nationalism, stability, equity and economic development.

\section{The Design of the Federal States}

The design of federal units and administrative structures, whether symmetric or asymmetric, may cause problems and conflict in the nation. As observed by Aalen (2002), as well as Yohannes and others (2005), the delimitation of the federal units in Ethiopia has not only created very dissimilar constituent parts and an asymmetrical federal system, but also many regional states with ethnic heterogeneity within their borders, and several states in which the competition between ethnic groups or clans for regional hegemony has led to destabilization and weakening of the regional governments.

In symmetric federal arrangements, all federal units have the same powers and the same number of representatives in a second chamber of parliament but in the case of asymmetric federation, all federal units do not have the same powers. For example, Ethiopia and Russia which employ high levels of incongruent and asymmetric federalism, respectively, have experienced moderate to high levels of conflict since adopting their most recent constitutional arrangements (Lancaster, 2012). Under symmetric federalism, sub-regional states are treated as equals as in the case of the United States but in asymmetric federalism, sub-national governments are treated differently, such as in Russia where each ethnic republic has its own president, whereas the Oblasts and the Krai have appointed governors (Lancaster, 2012).

A completely congruent system is one in which no federal subunit has a distinct social or cultural identity. For example, Ethiopia represents nearly complete incongruent federalism, with the boundaries for those states drawn up on ethno-linguistic lines. Ethiopia and Russia are somewhat similar in their designs of provincial units with Ethiopia a nearly incongruent federation featuring ethnically based subunits while Russia has extensive asymmetry with a non-trivial amount of subunits given special status in relation to the other federal subjects and the central government.

Citing the study of Lancaster (2012) shows that both incongruence and asymmetry have statistically significant effects on increasing the likelihood of conflict onset and the severity of conflicts. Groups that are not recognized under incongruent or asymmetric federations may organize protests to try to gain a greater level of recognition constitutionally (Lancaster, 2012). A case in point is the Hadiya and Wolaita ethnic groups in Ethiopia having millions of people and failed to get the status of a regional state whereas the Harari whose overall population is 246, 000 has been accorded a regional state. In the 2011-12 Ethiopian fiscal years, the Harari region received 
approximately higher annual budget than Hadiya and Wolaita Regional Zone since Hadiya and Woalita did not have the regional status level.

Therefore, inequitable distribution of wealth and poor fiscal management are said to cause problems in ethnic based politics. By considering the troubles that these particular ethnic groups'cases, we can understand that incongruent and ethnic federalism can be a potential source for grievance and conflict if an ethnic group is not recognized as important enough by the federal government.

Furthermore, ethnic federalism in Ethiopia does not consider the existing social reality of a society while projecting number of people in a specific ethnic group. In this regard, Assefa (2006) argues that a significant number of Ethiopians do not live in the places where the majority of the members of their ethnic group are to be found; they have moved, either voluntarily, in search of better opportunities, or by force, due to the Dergue's resettlement and villagisation.

\section{Fiscal Federalism}

Another important issue that needs much attention is the way in which money is distributed from the federal government to various regional states. In federation, central governments distribute funds to sub-national governments and there is a need to have effective systems of revenue sharing between the central and regional governments that could increase the effectiveness of the federal system. In distributing funds to sub-national governments, the central government could use a variety of fiscal federal criteria such as: population size, level of poverty and revenue generation capacity (Lancaster, 2012).

In Ethiopia, the powers of sub-national states are constitutionally protected, but in reality the forms of decentralization are quite limited by fiscal, political and administrative centralism (Dickovick, 2014). Due to the subjectivity of the parameters and the autocratic nature of the federal government, the fiscal federal funds are not distributed to the sub-regional governments in a genuinely fair way. Regional states in Ethiopia have alleged in the past that the EPRDF is mainly focused on disproportionately helping out the Tigray region (Lancaster, 2012).

Since the key federal government positions have been monopolized by one ethnic party, the TPLF of Tigray, there has never been a fair mechanism of allocating the finance. The balance of power clearly lies with the TPLF and the resulting inequalities give rise to situations of violent conflict. As a result, the management of the national resources does not serve the national objectives of realizing genuine development, reducing poverty and increasing the standard of living. Besides, in the absence of an effective, transparent and accountable system, the federal government dominates the process of fiscal distribution, which creates a sense of discontent among the various ethnic groups.

For the structures of fiscal federalism to function properly, there needs to be a fair and equitable distribution of financial resources between the central government and the states (regions). Where this does not happen, there will obviously be a strong potential for conflict. For instance, a great deal of dissatisfaction in the federal-provincial relationship in Pakistan has been observed around the distribution of financial resources (Abbasi, 2010). In the Ethiopian context, regional states have a weak fiscal autonomy and they have to depend on the federal government's allocation of funds, which is quite unbalanced (Lancaster, 2012).

\section{Dominant-Party Governance}

In a similar vein, dominant-party control along with an undemocratic nature of a given state could be another factor that could create conflict among ethnic groups. EPRDF in Ethiopia have dominated elections since the advent of federalism in the 1990s. Despite the fact that we are observing some reforms after Dr. Abiy Ahmed has came to power, the Ethiopian federal structure appears to be that of one-party state governance, which is characterized by highly concentrated and centralized powers maintained by totalitarian institutions such as the military, other security organs and state-controlled mass media. As it is quite evident today in Ethiopia, ethnic federalism coupled with the feeling of dominant party governance) provide valid reasons for the prevailing ethnic conflict in Ethiopia.

\section{Conclusion}

Entertaining identity politics in multi-lingual and multi-cultural societies in a way that protect nation from being fragmented is a bone of contention for most scholars in the social science disciplines. In this regard, the importance of having the correct approach is that it enables us to find relevant solutions: if we know what causes nation to be fragmented, then we can devise institutional mechanisms that remove the causes and, therefore, ease the problem. Accordingly, given the reality and entrenched nature of identity politics in Ethiopia, there are a lot to do so as to control and manage the country from being fragmented.

The first question is to know how historical narrations about nationhood, is reconstructed and reinterpreted by elites as a means to mobilize their respective ethnic members and satisfy their personal desire for the control of power. To alleviate this, I suggest that we should first create national consensus based at forgiveness regarding what was happened in the past.

I then take into consideration the deep rooted nature and challenges of applying identity politics in the federal 
state of Ethiopia. Accordingly, there is considerable evidence to suggest that ethnic federalism entails conflict since it politicizes tribal identity and scholars soundly refute its applicability, especially in the Ethiopian context. When it was introduced and developed, social critics and intellectuals have stated the negative consequences of ethnic federalism in the Ethiopian context since this nation is an ancient country having multi-cultural and multilingual societies that have been assimilated due to thousands of years of continuous interaction, intermarriage, trade, migration, and other social activities. In this regard, federalism, not ethnic, if appropriately applied, 'might be an effective method of bringing about political stability and order' but in the Ethiopian case, the politicization of ethnic identity by self-seeking political leaders causes political instability.

The desire of the self-seeking political leaders is manifested through the politicization of tribal identity; in their design of the federal states, their fiscal federalism and their dominant-party system. All these (politicization of tribal identity, design of the federal states, fiscal federalism and dominant-party) cause ethnic conflict, anomaly, and could finally drive the nation to be fragmented.

A way out to this critical problem is to stop politicizing human diversity and the ethnic federal arrangement in Ethiopia needs an urgent reconsideration. A non-ethnic and non-tribal multi-party democracy has to be established as the only workable option that could more effectively address the typical destruction of identity politics and promote feeling of nationalism among citizens.

\section{Reference}

Aalen, Lovise. (2002). Ethnic federalism in a dominant party state: The Ethiopian experience 1991-2000. Bergen, Michelsen Institute.

Abbasi, Zubair. (2010). Federalism, provincial autonomy and conflicts. Islamabad, Islamabad Centre for Peace and Development Initiatives (CPDI).

Alemayehu, G. Mariam. (2015). Why can't Ethiopia become like Ghana? Ethio-media News, 4 October.

Alemante, G. Selassie. (2003). Ethnic federalism: Its promise and pitfalls for Africa. The Yale Journal of International Law, 28 (51), pp. 51-107.

Assefa, Fiseha. (2006). Theory versus practice in the implementation of Ethiopia's ethnic federalism. In: Turton, David ed. Ethnic federalism: The Ethiopian experience in comparative perspective. Oxford, James Currey. pp. 131-164.

Dickovick, Tyler. (2014). Federalism in Africa: Origins, operation and (in) significance. Journal of African Affairs, 24 (5), pp. 553-570.

Holder, Christina, ZebaHuq, and Mary Catherine Ryan. (2006). Early warning in Ethiopia: Analysis.Human Rights and Genocide Clinic Cardozo, School of Law.

Lancaster, Ross. (2012). Federalism and civil conflict: The missing link? M.A. thesis. University of North Texas.

Legesse, Tigabu. (2015). Ethnic federalism and conflict in Ethiopia: What lessons can other jurisdictions draw? Africa Journal of International and Comparative Law, 23 (3), pp. 462-475.

MessayKebede. (2019). The Nature and Challenges of Ethnicity: The Case of Ethiopia. International Center, Michigan State University.

Mesfin, Wolde-Mariam. (1999). The Horn of Africa: Conflict and poverty. Addis Ababa, Commercial Printing Press.

Nnabuihe, N.S, Aghemalo, A. \&Okebugwu, N.E (2014).Ethnicity and electoral behaviour in Nigeria. European Scientific Journal /SPECIAL/ edition, 1857 - 7881.

Roxana, G.R., (2010). The Role of Ethnic Identity and Economic Issues in the 2007 Kenyan Elections. CSAE WPS/2010-06

TayeNegussie. (2018). In Pursuit of Truth and Justice: Critical Essays on Morality, Politics and Economy in Ethiopia and Beyond. LAP LAMBERT Academic Publishing, Mauritius.

Vestal, Theodore. (1999). Ethiopia: A post-cold war African State. Westport, Greenwood Publishing Group.

Yohannes, Gebre Michael, KassayeHadgu and ZerihunAmbaye. (2005). Addressing pastoralist conflict in Ethiopia. Africa Peace Forum, Ethiopian Pastoralist Research and Development Association. Inter Africa Group.

Zweiri M, Zahid M (2007). Religion, Ethnicity and Identity Politics In the Persian Gulf. Research Institute for European and American Research Paper No. 111 July 2007 Studies. 